\title{
The Effectiveness of Course Review Horay Learning Model with Adobe Flash Assistance to See Interests Aad Abilities
}

\section{Fina Idamatul Chilmi, Ibnu Sina, Wikan Budi Utami}

\author{
Pendidikan Matematika, Keguruan dan Ilmu Pendidikan, Universitas Pancasakti Tegal \\ finachilmi315@gmail.com, ibnusinaupstegal@gmail.com,wikan.piti@gmail.com
}

\begin{abstract}
Aim of this research to describe: 1) There are difference between math learning stake and ability solution to math problem which taught by Course Review Horay method Adobe Flashes aided, 2) Math learning stake and ability solution to math problem which taught by Course Review Horay method Adobe Flashes aided better than only Course Review Horay method. Data analysis technique that used are Right Side Proportion Test, T-tes One Right Side, Manova Test, and $\tau^{\wedge} 2$ Hotelling. Result of this research are: 1) There are difference between math learning stake and ability solution to math problem which taught by Course Review Horay method Adobe Flashes aided with only Course Review Horay method, 2) Math learning stake and ability solution to math problem which taught by Course Review Horay method Adobe Flashes aided better than only Course Review Horay method.
\end{abstract}

Keywords : Course Review Horay, Math Learning Stake, Ability Solution To Math Problem, Adobe Flash

\section{INTRODUCTIONS}

According to Kartana (2014), education is a conscious and planned effort to create an atmosphere of learning and learning process so that students actively develop their potential. Education is also believed to be a process of changing behavior in individuals, groups and organizations. The low quality of education at every level of education is a problem faced by the Indonesian people. Various attempts have been made, one of which is curriculum development, improvement of teacher competency, education management, use of media and teaching aids that are more maximized. One of the subjects taught to students in schools is mathematics.

According to Faz (2017), Mathematics is one of the subjects taught in schools since Elementary School (SD) or even preschool. Therefore, students should be familiar and love mathematics. Mathematics occupies an important role in the world of education, where mathematics is a subject that is the basis for other sciences so that mathematics is very important to learn. But in reality, many students find it difficult to complete mathematics so that not a few students who get grades are less satisfying. This can occur because interactions in the learning process are dominated by teachers which results in passive, non-creative and unmotivated students (Amaliyakh \& Isnani, 2015).

Talang 1 Junior High School is a school that applies the 2013 curriculum so that the learning model implemented is in accordance with the 2013 curriculum, which is the cooperative learning model. According to Ms. Nurfita Rosmida S.Pd as a grade VIII mathematics teacher, some students were indifferent, had little interest in learning 
mathematics especially to read the material being studied and still liked to play with other friends so they paid less attention to learning. Therefore, in the learning process sometimes teachers still use conventional learning models and questions and answers.

The teacher also states that when students are given question exercises, the teacher must appoint students to work forward because that way students want to work on the questions given and only 2 to 3 students who dare to come forward to solve the problem. Slameto (2010), states that interest is a sense of preferability and a sense of attachment to a thing or activity, without anyone asking. Thus the statement of the mathematics teacher at SMP Negeri 1 Talang which states that students must be appointed to move forward in order to work on the given problem, can be said that students' interest in learning mathematics is low. This is also shown from the average score below the Minimum Mastery Criteria (KKM) and only 26\% of students who exceeded the KKM is 70 at the Odd End of Semester (PAS) school year 2018/2019.

One of the goals of learning mathematics is understanding mathematical concepts, explaining the interrelationships between concepts or algorithms flexibly, accurately, efficiently and precisely in problem solving (Duha, 2012). Based on the purpose of learning mathematics, problem solving skills become an important component that must be possessed in learning. This is reinforced by Husna (Simanungkalit, 2016), that the ability to solve problems is something that is very important for students to have in achieving the curriculum. Furthermore (Anisa, 2014), that learning mathematics if successful, among others, will produce students who have problem-solving abilities, communication skills, reasoning abilities, understanding abilities and other abilities well and are able to take advantage of the usefulness of mathematics

in

life.

Based on the results of an interview with Ms. Diah Ekawati S.Pd as a mathematics teacher in class VIII, that the ability of students in SMP Negeri 1 Talang is classified as heterogeneous due to the influence of zoning on student acceptance. In addition, there are still many students who have difficulty in solving problems that are not routine, especially a matter of stories where students do not understand the problem so that it is not right in making plans that will be applied in solving problems that result in incorrect answers.

The cube and the block are the material that class VIII students learn in the even semester. Based on the results of Nurmavia's research (2011), that one of the difficulties experienced by students in learning the material of flat side space is: difficulty understanding and using the concept of comparison between volume and surface area. In addition, Ms. Nurfita Rosmida S.Pd said that students had difficulty in imagining a hollow cube so that it was difficult to understand the concepts taught and the material had been studied in elementary schools where students lacked understanding of the material of the cube and blocks which caused the students to be bored and not likes to relearn, which in the end the learning achievement on geometry material becomes low. This is what underlies the selection of cubes and beams as material to be studied.

One way to overcome these problems is to use the Course Review Horay learning model because the Course Review Horay learning model can create a lively classroom atmosphere and can help students understand concepts well through group discussions (Eliyah, Isnani and Utami, 2018). Course Review Horay learning model is a learning model that requires the cooperation of students with other students to solve problems in which there is a test of students' understanding of concepts in solving problems by means of answers to questions written on cards that have been equipped 
with numbers so as to create a classroom atmosphere fun that can make students active in the learning process because every group that gets the right sign must shout "horay" or yells that have been determined by the group beforehand.

In the process of learning mathematics often learning media are needed in order to make it easier for teachers to deliver material to students. However, according to Ms. Diah Ekawati S.Pd the media used in learning are only modules without utilizing computer-related media even though the facility is in school. Therefore, the use of Adobe Flash learning media is one alternative to facilitate students in understanding the concept of cubes and blocks which of course with interactive elements. This is reinforced by Darari (2017), that Adobe Flash media can improve problem solving abilities and motivation of high students.

According to previous research conducted by 1) Risma Nurul Auliya (2013), it was found that there was an increase in students' mathematics learning achievement taught by the Caurse Review Horay type cooperative learning model. 2) Amelia, F., \& Siahaan, F. H. (2016) found that the CRH learning model was effective in terms of student mathematics learning outcomes on the subject matter of prism and pyramid spaces in class VIII of Laksamana Middle School Batam. 3) Eliyah (2018), the results show that the confidence and mathematics learning achievement of students taught using the Course Review Horay learning model assisted by Microsoft Power Point is better than those taught using conventional learning models.

In contrast to previous studies, this study uses Adobe Flash learning media. The use of Adobe Flash as a learning medium is useful for teachers to prepare teaching materials and can be used as aids in the teaching and learning process. Adobe Flash media can stimulate students' stimulus to be able to manipulate existing concepts and can find out the real form of abstract mathematical concepts (Umam and Yudi, 2016). Based on the problem that has been explained in the results of an interview with one of the teachers in SMP Negeri 1 Talang and the results of the existing research, in this study further research will be conducted under the title "The Effectiveness of Adobe Flash Assisted Course Review Horay Assistance for Interest and Mathematical Problem Solving Ability (Research Study on Class VIII Students in Semester II Middle School 1 Talang, Tegal Regency, 2018/2019 Academic Year on Cubes and Beams) ".

The objectives of this study are: 1) Describe whether the mathematical problem solving abilities of students taught using the Adobe Flash Course Review Horay learning model whose value is above 70 exceeds $53.125 \%$, 2) Describe whether the learning interest of students taught using the Course Review Horay learning model Adobe Flashassisted is better than students taught using the Course Review horay learning model, 3) Describe the mathematical problem solving ability of students taught using the Course Review Horay learning model Adobe Flash-assisted better than students taught using the Course Review Horay learning model , 4) Describe whether there are differences in interest in learning mathematics and the ability to solve mathematical problems between students taught using the Adobe Flash Course Review learning model assisted by Adobe Flash and students taught using the p model Course Review Horay learning, 5) Describe interest in learning mathematics and mathematics problem solving skills of students taught using Adobe Flash Course Review Horay learning models better than students taught using the Course Review Horay learning model 


\section{RESEARCH METHOD}

The approach used in this study is a quantitative approach because the data obtained in the form of numbers and allows the use of statistical data analysis techniques. The population used was all students of class VIII SMP 1 Talang odd semester 2018/2019 consisting of 9 classes with a total of 288 students. In this study the sample to be used consisted of 3 classes with a total of 96 students. The sampling technique was Cluster Random Sampling obtained by class VIII C as the experimental class I, class VIII F as the experimental class II, and class VIII A as the experimental class. Data collection techniques used were documentation, mathematics interest questionnaire and mathematics problem solving ability tests.

In the data analysis technique there are 2 stages. First, before conducting the research, the analysis prerequisite test is carried out first, namely the sample equivalence test consisting of normality test, homogeneity test and one-way anova test. Then the instrument of mathematical problem solving ability test is performed which consists of validity, reliability, different power and difficulty levels. The second step is testing the hypothesis. Before a hypothesis test is performed, a prerequisite test is carried out, ie univariate normality and homogeneity tests as a condition in calculating the RightHanded One-t-Test. After the data is normally distributed and univariate homogeneous, the Right-Party One-tailed Test can be performed. In addition, the Manova Test requirements in the calculation must be normally distributed and homogeneous. In this study the normality and homogeneity tests used are multivariate normality and homogeneity tests. After the data is normally distributed and multivariate homogeneous, the Manova Test can be performed. Then, proceed with the hypothesis test consisting of the Right-Party Proportion Test, Right-Party One-t Test, Manova Test, and Hotelling Test.

\section{RESULTS}

This research was conducted at Talang 1 Junior High School, located on Jl. Projosumarto II No. 11 Talang District, Tegal Regency which took place on 18 March 2019 until 20 April 2019 during 5 meetings with materials of cubes and blocks. The sample in this study consisted of 3 classes, namely the experimental class (VIII A), the experimental class I (VIII C) and the experimental class II (VIII F) with 96 students. Of the three classes having equal ability, this is evident from the grades obtained by students in the Final Assessment Semester (PAS) odd mathematics subjects in class VIII of SMP Negeri 1 Talang in the academic year 2018/2019.

Description of students' interest in learning mathematics between experiment class I and experiment II is as follows: 
Table 1 Data Description of Interest in Learning Mathematics

\begin{tabular}{ccrr}
\hline No & Standard & Eksperiment I & Eksperiment II \\
\hline 1 & Mean & 78,935 & 70,656 \\
2 & Median & 80 & 73 \\
3 & Modus & 73 & 66 \\
4 & St. Deviasi & 8,714 & 8,495 \\
5 & Variansi & 75,929 & 72,168 \\
6 & Max & 93 & 86 \\
7 & Min & 58 & 49 \\
8 & CV & 0,110 & 0,120 \\
\hline
\end{tabular}

Based on Table 1, it can be seen the difference in data from each treatment. The description of mathematics learning interest data shows that the mean value of the experimental class I taught using the Adobe Flash assisted Course Review learning model is higher than the experimental class II taught using the Course Review Horay learning model of 78,903> 70,563. The $\mathrm{CV}$ value of mathematics learning interest in the experimental class I was also lower, 0.110 than the experimental class II, which was 0.120. In addition, by looking at the median value and the experimental class I mode shows higher than the experimental class II. The description of the data above shows that students taught using the Adobe Flash Course Review learning model assisted by Adobe Flash have a better interest in learning mathematics than students who are taught using the Course Review Horay learning model.

The data description of students' mathematical problem solving abilities between the experimental class I and experiment II is as follows:

Table 2 Data Description of Mathematical Problem Solving Ability

\begin{tabular}{ccrr}
\hline No & Standard & Eksperiment I & Eksperiment II \\
\hline 1 & Mean & 76,581 & 70,563 \\
2 & Median & 76 & 72 \\
3 & Modus & 78 & 64 \\
4 & St.Deviasi & 7,903 & 7,641 \\
5 & Variansi & 62,452 & 58,383 \\
6 & Max & 94 & 90 \\
7 & Min & 58 & 50 \\
8 & CV & 0,103 & 0,108 \\
\hline
\end{tabular}

Based on Table 2, it can be seen the difference in data from each treatment. The description of students' mathematical problem solving ability data shows that the mean value of the experimental class I taught using the Adobe Flash assisted Course Review Horay learning model is higher than the experimental class II taught using the Course Review Horay learning model which is 76,581> 70,563. The CV value of the mathematical problem solving ability of the experimental class I was also lower, 0.103 than the experimental class II, which was 0.108. In addition, by looking at the median value and the experimental class I mode shows higher than the median value and mode 
of the experimental class II. The description of the data above shows that students who are taught using the Adobe Flash Course Review learning model assisted by Adobe Flash have better mathematical problem solving abilities than students who are taught using the Course Review Horay learning model.

Results Analysis of the ability to solve mathematical problems with the Right One-Part Proportion Test

To determine whether the students' mathematical problem-solving abilities taught using the Adobe Flash-assisted Course Review Horay learning model with a value above 70 exceeds $53.125 \%$, then the Right-One Proportion Test is conducted. The summary of calculations is as follows:

Table 3: Data Analysis Results of Mathematical Problem Solving Capabilities with the Right Part One Proportion Test

\begin{tabular}{lrr}
\hline$Z_{\text {count }}$ & $Z_{\text {table }}$ & Conclution \\
\hline 2,351 & 1,645 & $2,351>1,697$ \\
\hline
\end{tabular}

Based on the calculation using the Right One-Part Proportion Test analysis, the value of $\mathrm{Z}_{\text {count }}=2.351$ is obtained. The results were then consulted with $\mathrm{Z}_{\text {table }}$ at the $5 \%$ significance level obtained $Z_{\text {table }}=1.697$. Because $Z_{\text {count }}>Z_{\text {table }}$ or 2.351>1.697 it can be concluded that Ho is rejected. So, the ability to solve mathematical problems taught using the Adobe Flash Course Review learning model assisted by Adobe Flash values above 70 exceeds $53.125 \%$

Results of Analysis of interest in learning mathematics with the Right-Handed One-tTest

To determine whether students' interest in learning mathematics taught using the Course Review Horay learning model assisted by Adobe Flash is better than students who are taught using the Course Review Horay learning model, then the Right One-Party T-Test is conducted. The summary of calculations is as follows:

Table 4 Results of Data Analysis of Interest in Learning Mathematics With the RightHanded One-t Test

\begin{tabular}{rrc}
\hline $\mathrm{T}_{\text {count }}$ & $\mathrm{T}_{\text {table }}$ & Conclution \\
\hline 3,891 & 1,671 & $3,891>1,671$ \\
\hline
\end{tabular}

Based on the calculation using the Right-Handed One-tailed T-test analysis, the value of $\mathrm{t}_{\text {count }}=3.891$ was obtained. The results were then consulted with the distribution list $\mathrm{t}$ value with $\mathrm{dk}=\left(\mathrm{n}_{1}+\mathrm{n}_{2}-2\right)$ and $\alpha=5 \%$ obtained distribution table $(0.975(61))=1.671$. 
Because $t_{\text {count }}>t_{\text {table }}$ or $3.891>1.671$ it can be concluded that Ho is rejected. So, the interest in learning mathematics of students taught using the Course Review Horay learning model assisted by Adobe Flash is better than students who are taught using the Course Review Horay learning model.

Results of the analysis of mathematical problem-solving abilities using the RightHanded

One-t-Test

To determine whether the mathematical problem-solving abilities of students taught using the Adobe Flash assisted Course Review Horay learning model are better than those of students taught using the Course Review Horay learning model, then the RightHanded One-Party t-test is conducted. The summary of calculations is as follows:

Table 5 Results of Data Analysis of the Ability to Solve Mathematical Problems with the Right-Handed T-Test

\begin{tabular}{ccc}
\hline $\mathrm{t}_{\text {count }}$ & $\mathrm{t}_{\text {table }}$ & Conclution \\
\hline 3,073 & 1,671 & $3,073>1,671$ \\
\hline
\end{tabular}

Based on the calculation using the right hand t-test analysis, the value of $t_{\text {count }}=3.073$ is obtained. The results are then consulted with the distribution list value $t$ with $d k=\left(n_{1}+\right.$ $\left.\mathrm{n}_{2}-2\right)$ and $\alpha=5 \%$ obtained distribution table $(0.975(61))=1.671$ with a real level $\alpha=$ $5 \%$. Because $t_{\text {count }}>t_{\text {table }}$ or 3.073>1.671 it can be concluded that Ho is rejected. So, the mathematical problem solving ability of students taught using the Adobe Flash assisted Course Review learning model is better than students taught using the Course Review Horay learning model.

Results of Data Analysis of interest in learning mathematics and the ability to solve mathematical problems with the Manova Test

To determine whether there are differences in interest in learning mathematics and the ability to solve mathematical problems between students taught using the Adobe Flash Course Review Horay learning model and students who are taught using the Course Review Horay learning model the Manova Test is conducted. The summary of calculations is as follows:

Table 6 Results of Data Analysis of Interest in Learning Mathematics and Ability to Solve Mathematical Problems With the Manova Test

\begin{tabular}{lcccc}
\hline Source of variance & DB & JK dan JKH & $\lambda_{\text {count }}$ & $\lambda_{\text {table }}$ \\
\hline treatment $(\mathrm{H})$ & 1 & $\mathrm{H}=\left[\begin{array}{ccc}1.079,323 & 784,556 \\
784,556 & 570,291\end{array}\right]$ \\
& & & \\
Galat $(\mathrm{E})$ & 62 & $\mathrm{E}=\left[\begin{array}{ll}4.515,090 & 3.623,349 \\
3.623,349 & 3.683,423\end{array}\right]$ & 0,802 & 0,903 \\
& & & \\
Total $(\mathrm{T})$ & 63 & $\mathrm{~T}=\left[\begin{array}{ll}5.594,413 & 4.407,905 \\
4.407,905 & 4.253,714\end{array}\right]$ & \\
\hline
\end{tabular}


Based on the results of calculations using the Manova test obtained $\lambda_{\text {count }}=0,802$. The results were then consulted $\lambda_{\text {table }}$ with $\mathrm{p}$ (number of response variables) $=2, V_{H}=$ degree of free treatment $=1$ and $V_{E}=$ degree of error free $=63$ and significance level of $5 \%$, then obtained $\lambda_{\text {table }}=0,903$. Because $\lambda_{\text {count }}<\lambda_{\text {table }}$ or $0.802<0.903$ it can be that Ho is rejected which means there is a difference between interest in learning mathematics and the ability to solve mathematical problems taught by the Caurse Review Horay learning model assisted by Adobe Flash and those taught by the Caurse Review Horay learning model.

Results of Data Analysis of interest in learning mathematics and the ability to solve mathematical problems with the $\boldsymbol{\tau}^{2}$ - HotellingTest

To determine whether the interest in learning mathematics and the ability to solve mathematical problems taught by the Adobe Flash Course Review learning model assisted by Adobe Flash is better than the Course Review Horay learning model, the ling $\boldsymbol{\tau}^{2}-$ Hotelling Test was conducted. The summary of calculations is as follows:

Table 7 Results of Data Analysis of Interest in Learning Mathematics and Ability to Solve Mathematical Problems With the Manova Test with $\mathbf{\tau}^{2}-$ Hotelling Test

\begin{tabular}{ccc}
\hline$\tau^{2}{ }_{\text {count }}$ & $\tau^{2}$ table & Conclution \\
\hline 9,089 & 6,413 & $9,089>6,413$ \\
\hline
\end{tabular}

Based on the results of calculations using the $\tau^{2}-$ Hotelling test obtained $\tau^{2}$ count $=9,089$. The results were then consulted $\tau^{2}$ table with $\mathrm{p}$ (number of response variables) $=2, \mathrm{VH}$ $(\mathrm{db}$ treatment $)=1$ and VE $(\mathrm{db}$ error $)=62$, and significance level of $5 \%$, then obtained $\tau^{2}$ table $=6,413$. Because $\tau^{2}$ count $>\tau^{2}$ table or 9,089> 6,413 then Ho is rejected, meaning that the interest in learning mathematics and the mathematical problem solving ability of students taught using the Caurse Review Horay assisted Adobe Flash model are better than those taught by Adobe Flash. using the Caurse Review Horay learning model.

Based on the results of research conducted at Talang 1 Junior High School in class VIII students in semester II of the 2018/2019 academic year on cube and beam material shows that the mathematical problem solving ability taught by the Adobe Flash Course Review Horay learning model reaches the target. This is because in learning Course Review Horay aided by Adobe Flash the teacher facilitates students in making summaries, directing, and giving confirmation on the material that has been learned which of course with interactive elements. This is in accordance with Darari (2017: 40), that Adobe Flash media can improve problem solving abilities and motivation of high students.

Based on the results of research interest in learning mathematics and mathematical problem solving skills taught using the Adobe Flash Caurse Review Horay learning model is better than those taught using the Caurse Review Horay learning model. This is because the Course Review Horay learning model is a learning model that requires the cooperation of students with other students to solve problems from the problems that have been given by interspersed with entertainment that makes the atmosphere not tense. That way students are more eager to participate in learning and can generate interest in learning mathematics. In addition, the addition of learning media in the form of Adobe Flash media during the learning process can also create a more interesting learning 
atmosphere and make it easier for students to understand the concept of cubes and blocks.

Based on the results of the study there is a difference between interest in learning mathematics and the ability to solve mathematical problems taught by the Adobe Flash Caurse Review Horay learning model and those taught by the Caurse Review Horay learning model. This is because of the different stages of learning in each learning model that is applied where in the experimental class I the addition of learning media. Adobe Flash Caurse Review assisted aims to increase interest in learning mathematics. With a high interest in learning mathematics, the learning process will go well so that students in learning do not get bored easily, can concentrate, easy to remember the material being learned and easy to communicate with other students who will eventually be excited if given a problem to find solutions to these solutions. That way students will be easier to solve a given problem.

Based on the results of research interest in learning mathematics and mathematical problem solving skills taught using the Adobe Flash Caurse Review Horay learning model is better than those taught using the Caurse Review Horay learning model. This is in accordance with Eliyah, Isnani and Utami (2018: 132) that the Course Review Horay learning model can create a lively classroom atmosphere and can help students understand concepts well through group discussions. In addition, it is also in line with Umam and Yudi (2016: 86) that Adobe Flash media can stimulate students' stimulus so that they can manipulate existing concepts and can find out the real form of abstract mathematical concepts. That way, students have no difficulty in understanding the material of cubes and blocks.

According to Sholikhakh, et al (2019: 33-39), effectiveness in the learning model is the result obtained from the learning process, which is good in completing the KKM, using a better model, and there are differences from the model with the previous model. Based on the results of research conducted, it can be concluded that the learning model of Adobe Flash Caurse Review is more effective than the learning model of Caurse Review Horay on cube and beam material.

\section{CONCLUSION}

Based on the results of data analysis and the results of the discussion in a study conducted on students of class VIII Semester II Middle School 1 Talang Academic Year 2018/2019, the following conclusions are obtained:

1. Mathematical problem-solving abilities of students taught using the Adobe Flash Course Review Horay learning model whose scores are above 70 exceeds $53.125 \%$.

2. The interest in learning mathematics of students taught using the Course Review Horay learning model assisted by Adobe Flash is better than students who are taught using the Course Review Horay learning model.

3. Mathematical problem-solving abilities of students taught using the Adobe Flash Course Review Horay learning model are better than those of students taught using the Course Review Horay learning model.

4. There is a difference between the interest in learning mathematics and the ability to solve mathematical problems of students who are taught using the Adobe Flash Caurse Review Horay learning model and students who are taught using the Caurse Review Horay learning model. 
5. The interest in learning mathematics and the ability to solve mathematical problems of students taught using the Adobe Flash Caurse Review learning model is better than that of students taught using the Caurse Review Horay learning model.

\section{REFERENCES}

Amaliyakh, R., \& Isnani, I. (2015). EFEKTIVITAS STRATEGI PEMBELAJARAN STUDENT TEAM HEROIC LEADERSHIP (STHL) DAN PEMBERIAN TUGAS TERSTRUKTUR TERHADAP KETUNTASAN BELAJAR MAHASISWA DALAM MATAKULIAH ANALISIS REAL DI PROGRAM STUDI PENDIDIKAN MATEMATIKA FKIP UNIVERSITAS PANCASAKTI TEGAL. Jurnal Dialektika Program Studi Pendidikan Matematika, 2(2), 1-9.

Amelia, F., \& Siahaan, F. H. (2016). PERBANDINGAN MODEL PEMBELAJARAN KOOPERATIF TIPE COURSE REVIEW HORAY DENGAN TIME TOKEN ARENDS TERHADAP HASIL BELAJAR MATEMATIKA SISWA KELAS VIII DI SMP LAKSAMANA BATAM TAHUN PELAJARAN 2014/2015. PYTHAGORAS: Jurnal Program Studi Pendidikan Matematika, 4(2).

Anisa, W. N. (2014). Peningkatan kemampuan pemecahan masalah dan komunikasi matematik melalui pembelajaran pendidikan matematika realistik untuk siswa smp negeri di kabupaten garut. Jurnal Pendidikan dan Keguruan, 1(1).

Auliya, R. N. (2013). Pengaruh Model Pembelajaran Kooperatif Tipe CRH (Course, Review, Hurray) Terhadap Kemampuan Pemahaman Matematis dan Kecemasan Matematika Siswa SMP(Doctoral dissertation, Universitas Pendidikan Indonesia).

Darari, M. B. (2017). PENGGUNAAN MEDIA ADOBE FLASH PADA PEMBELAJARAN KESEBANGUNAN DALAM MENINGKATKAN KEMAMPUAN PEMECAHAN MASALAH MATEMATIKA SISWA SMP NEGERI 7 MEDAN. JURNAL HANDAYANI PGSD FIP UNIMED, 7(2), 2937.

Duha, A. K. (2012). Penerapan Model Think Pair Share Terhadap Pemahaman Konsep. Jurnal Pendidikan Matematika, 1(1).

Eliyah, S., Isnani, I., \& Utami, W. B. (2018). KEEFEKTIFAN MODEL PEMBELAJARAN COURSE REVIEW HORAY BERBANTUAN POWER POINT TERHADAP KEPERCAYAAN DIRI DAN PRESTASI BELAJAR. S-MAT (Jurnal Edukasi dan Sains Matematika), 4(2), 131-140.

Faz, Ahmad Toha. 2017. Matematika Detik "Insprirasi, Fondasi, dan Garis Besar". Surakarta : PT. Aksarra Sinergi Media.

Kartana, Tri Jaka. 2014. Manajemen Pendidikan. Tegal: Badan Penerbitan Universitas Pancasakti.

Nurmavia, A. (2011). Diagnosis Kesulitan Belajar dan Pengajaran Remidinya Materi Bangun Ruang Sisi Datar Siswa Kelas VIII SMP Negeri 4 Kepanjen Kabupaten Malang. SKRIPSI Jurusan Matematika-Fakultas MIPA UM.

Simanungkalit, R. H. (2016). Pengembangan Perangkat Pembelajaran untuk Meningkatkan Kemampuan Pemecahan Masalah Matematis Siswa SMP Negeri 12 Pematangsiantar. MUST: Journal of Mathematics Education, Science and Technology, 1(1), 39-56. 
Sholikhakh, R. A., Pujiarto, H., \& Suwandono, S. (2019). Keefektifan Model Pembelajaran Problem Based Learning terhadap Minat dan Prestasi Belajar Matematika. Journal of Medives: Journal of Mathematics Education IKIP Veteran Semarang, 3(1), 33-39.

Slameto. 2010. Belajar dan Faktor-Faktor Yang Mempengaruhinya. Jakarta: Rineka Cipta.

Umam, K., \& Yudi, Y. (2016). Pengaruh Menggunakan Software Macromedia Flash 8 Terhadap Hasil Belajar Matematika Siswa Kelas VIII. KALAMATIKA Jurnal Pendidikan Matematika, 1(1), 84-92.) 